\title{
IMPLEMENTASI PROGRAM CYBER PUBLIC RELATIONS PT. KERETA API INDONESIA DALAM MENGELOLA INFORMASI PUBLIK DI MEDIA SOSIAL INSTAGRAM
}

\author{
Anindita Susilo ${ }^{1}$; Erlina Sari ${ }^{2}$ \\ 1\&2Program Studi Ilmu Komunikasi, FIKOM Universitas Mercu Buana \\ email:1anindita@mercubuana.ac.id,2erlinasa311@gmail.com
}

\begin{abstract}
Abstrak
Di tahun 2011, pemberitaan PT. KAI cenderung ke arah negatif dalam memberikan pelayanan. Namun di tahun 2014, hal tersebut menjadi semakin baik. Prestasi yang diperoleh PT. KAI tersebut tidak lepas dari faktor pengelolaan informasi publik yang disosialisasikan lewat media sosial melalui program Cyber Public Relations. Penelitian ini ditujukan untuk mengetahui implementasi program Cyber Public Relations PT. Kereta Api Indonesia dalam mengelola informasi publik di media sosial Instagram @keretaapikita. Penelitian ini menggunakan konsep pengelolaan program Public Relations yang diinisiasi oleh Cutlip yang kemudian dikaitkan dengan konsep Cyber PR. Metode penelitian yang digunakan adalah deskriptif analisis dengan pendekatan kualitatif. Informan penelitian adalah Head Manager Web Corporate, BUMN Portal and Social Media, Humas dan Assistant Manager Web Corporate, BUMN Portal and Social Media, admin media sosial Instagram @keretaapikita, serta pengguna jasa dan followers Instagram PT. Kereta Api Indonesia. Hasil penelitian menunjukkan bahwa implementasi program Cyber Public Relations PT. Kereta Api Indonesia dalam mengelola informasi publik di media sosial Instagram meliputi memberikan informasi tentang PT. Kereta Api Indonesia (Persero), layanan kereta api, layanan stasiun sampai event dan inovasi yang telah dilakukan, bahkan beberapa kali dilakukan kegiatan giveaway. Hal tersebut tidak lepas dari tujuan utamanya, yaitu menunjang kegiatan manajemen dalam mencapai tujuan organisasi, membina hubungan harmonis antara organisasi dengan publik eksternal maupun internal, menciptakan komunikasi dua arah secara timbal balik dengan menyebarluaskan informasi dari perusahaan kepada publik dan menyalurkan opini publik kepada organisasi, dan melayani publik dan menasehati pimpinan organisasi kepentingan umum.
\end{abstract}

Kata Kunci: Cyber PR, PT. Kereta Api Indonesia, Informasi Publik

\begin{abstract}
In 2011, the news about PT. KAI tends to be negative in providing services. However, in 2014, things are getting better. Achievements obtained by PT. KAI are inseparable from the factor of public information management that is socialized through social media by Cyber Public Relations program. This study aimed to determine the implementation of the Cyber Public Relations program of PT. Kereta Api Indonesia in managing public information on social media Instagram @keretaapikita. This study uses the concept of managing Public Relations programs initiated by Cutlip which is then associated with the concept of Cyber PR. The research method used is descriptive analysis with a qualitative approach. The informant of this research includes Head Manager Web Corporate, BUMN Portal and Social Media, PR and Assistant Manager Web Corporate,
\end{abstract}


BUMN Portal and Social Media, admin of @keretaapikita Instagram account, as well as users and followers of PT. Kereta Api Indonesia's Instagram account. The results showed that the implementation of the Cyber Public Relations program of PT. Kereta Api Indonesia in managing public information on social media Instagram includes providing information about PT. Kereta Api Indonesia (Persero), train services, station services to events and innovations that have been carried out, even a number of giveaway activities have been carried out. This is inseparable from its main objectives, which are supporting management activities in achieving organizational goals, fostering harmonious relations between organizations with external and internal public, creating reciprocal two-way communication by disseminating information from the company to the public and channeling public opinion to the organization, and serving the public and advising leaders of public interest organizations.

Key Words: Cyber PR, PT. Kereta Api Indonesia, Public Information

\section{PENDAHULUAN}

Internet, khususnya media sosial, saat ini tidak hanya digunakan oleh individu, namun juga oleh perusahaan. Maka dari itu, muncul istilah baru di bidang kehumasan, yaitu Cyber Public Relations. Secara garis besar Cyber PR merupakan kegiatan kehumasan yang dilakukan dengan menggunakan internet untuk membangun atau mempertahankan sebuah merek, kepercayaan, dan citra organisasi kepada khalayak yang bersifat interaktif. Saat ini aktivitas Public Relations mayoritas dilakukan secara online, khususnya pada perusahaan yang bergerak dalam bidang agen perjalanan online (Susilo \& Putra, Juli 2019). Salah satu perusahaan yang mengimplementasikan aktivitas Cyber Public Relations adalah PT. Kereta Api Indonesia yang merupakan Badan Usaha Milik Negara yang menyediakan, mengatur, dan mengurus jasa angkutan kereta api di Indonesia.

Penelitian yang dilakukan oleh (Januarti, 2014) menyatakan bahwa 39\% pemberitaan PT. KAI di tahun 2011 cenderung ke arah negatif dalam memberikan pelayanan. Namun di tahun 2014, hal tersebut menjadi semakin baik dibawah kepemimpinan Ignasius Jonan sebagai Direktur Utama PT. KAI. Angkutan lebaran 2014 adalah puncak gunung es dari sebuah proses perubahan yang berlangsung evolusioner di seluruh lini korporasi PT. Kereta Api Indonesia. Setelah itu, jumlah penumpang kereta api pun meningkat dengan cukup pesat. Prestasi PT. KAI tidak hanya berhenti sampai hal tersebut (Djuraid, 2013). Pada tahun 2017, PT. KAI kembali meraih penghargaan dalam ajang Apresiasi Indonesia untuk BUMN 2017 yang digelar oleh majalah Warta Ekonomi untuk mengapresiasikan perusahaan BUMN yang memiliki kinerja baik dalam 3 Tahun terakhir dan berdasarkan total pemberitaan dengan tone positif pada media sosial.

Prestasi yang diperoleh PT. KAI tersebut tidak lepas dari faktor pengelolaan informasi publik yang disosialisasikan lewat media sosial melalui program Cyber Public Relations. Pemanfaatan media sosial diharapkan dapat memudahkan akses pengguna kereta api dalam mendapatkan informasi. Salah satu akun media sosial yang dimiliki PT. Kereta Api Indonesia adalah Instagram @keretaapikita yang resmi dibuat pada tanggal 10 April 2012. Di tiga tahun pertama, akun Instagram PT. Kereta Api Indonesia belum begitu banyak pengikutnya, yaitu hanya sekitar 2.636 orang dan 550 post. Namun seiring dengan perkembangan teknologi, akun Instagram tersebut mengalami kenaikan yang cukup drastis yaitu 342.000 orang, dengan jumlah postingan sebanyak 1,888 post. Jika dibandingkan dengan media sosial lain yang 
dimiliki oleh PT. Kereta Api Indonesia, Instagram nya bersifat lebih aktif dan lebih banyak pengikutnya. Dari data mengenai penetrasi penggunaan Instagram PT. KAI, dapat disimpulkan bahwa masyarakat lebih banyak menggunakan Instagram dalam melihat informasi PT. KAI.

Perkembangan teknologi informasi pada era globalisasi ini memberikan dampak yang sangat besar pada berbagai aspek, salah satunya adalah kehadiran jaringan internet yang pada akhirnya melahirkan beragam jenis media sosial. Saat ini, media sosial telah menjadi kebutuhan utama bagi manusia untuk pemenuhan kebutuhan informasi maupun kepuasan pribadi. Berdasarkan data yang dirilis oleh We Are Social, pengguna media sosial secara total Indonesia tumbuh sebanyak $17 \%$ dari tahun 2019 ke tahun 2020. Tercatat ada 175,4 juta pengguna internet di Indonesia pada bulan Januari 2020, dimana 160 juta diantaranya adalah pengguna media sosial (Kemp, 2020).

Berdasarkan dari uraian latar belakang di atas, maka yang menjadi fokus dalam riset ini adalah: "Bagaimana Implementasi Program Cyber Public Relations PT. Kereta Api Indonesia dalam Mengelola Informasi Publik di Media Sosial Instagram?" Sesuai dengan permasalahan dan fokus penelitian, maka tujuan penelitian yang ingin dicapai dari penelitian ini adalah untuk mengetahui implementasi program Cyber Public Relations PT. Kereta Api Indonesia dalam mengelola informasi publik di media sosial Instagram.

Penelitian tentang Cyber Public Relations tentunya sudah banyak dilakukan oleh peneliti lain, mulai dari strategi, pola, implementasi, sampai dengan evaluasi kegiatan. Berikut ini adalah beberapa penelitian terdahulu yang telah dilakukan oleh peneliti lain:

Penelitian pertama berjudul "Activities of Cyber PR of O Channel TV in Promoting Their Company on Instagram" dilakukan oleh Kurniastuti Kusuma dan dipublikasikan di American Journal of Humanities and Social Sciences Research (AJHSSR). Penelitian yang menggunakan metode deskriptif kualitatif ini bertujuan untuk menjelaskan dan menganalisa aktivitas cyber PR di O'Channel TV. Hasil dari penelitian menunjukkan bahwa Instagram digunakan sebagai media untuk mempromosikan berbagai program dan aktivitas cyber PR yang dilakukan meliputi penjadwalan, monitoring, merespon, membuat pesan dan melakukan evaluasi (Kusuma, 2018). Penelitian kedua dilakukan oleh Inez Gabrina dan Suharyanti dengan judul Analisis Strategi Cyber PR PT. Pertamina (Persero) untuk Sosialisasi Penyesuaian Harga LPG 12 kg (Studi Kasus pada Kompetisi Blog Kompasiana oleh Pertamina). Penelitian ini menggunakan metode studi kasus untuk mengetahui latar belakang dipilihnya cyber PR sebagai salah satu strategi sosialisasi. Hasil penelitian menunjukkan bahwa sosialisasi LPG $12 \mathrm{~kg}$ melalui strategi cyber PR sudah cukup strategis dan memicu respon positif masyarakat, terbukti dari intensitas gejolak pada publik yang jauh berkurang (Gabrina, 2013).

Penelitian selanjutnya berjudul Strategi Cyber PR dalam Pembentukan Citra Institusi Pendidikan Tinggi Swasta yang dilakukan oleh Gita Aprinta. Dalam penelitian ini dapat disimpulkan bahwa cyber PR memberikan arti baru untuk praktisi PR khususnya dalam membentuk image positif universitas swasta. Melalui cyber PR, komunikasi antara PTS dan publik dapat dijembatani dengan lebih cepat dan lebih mudah (E.B, 2014). Sebelum melaksanakan penelitian ini, peneliti pernah melakukan penelitian yang berjudul Strategi Cyber PR pada perusahaan Start-Up dalam Membangun Brand Awareness (Studi pada Perusahaan Start-Up Jendela 360). 
Penelitian tersebut bertujuan untuk mendeskripsikan strategi cyber PR yang digunakan oleh Jendela360 untuk membangun Brand Awareness karena aktivitas dari perusahaan start up banyak dilakukan di dunia maya. Metode yang digunakan dalam penelitian ini adalah deskriptif kualitatif dengan metode pengumpulan data berupa wawancara. Hasil dari penelitian menunjukkan bahwa bahwa strategi cyber PR yang dilakukan oleh Jendela360 sebagai perusahaan start up dalam membangun brand awarenessnya adalah dengan meningkatkan SEO melalui tulisan, release dan posting di media sosial (Susilo \& Putra, Juli 2019).

Penelitian tentang pemanfaatan media sosial juga pernah dilakukan oleh Nurjanah dengan judul Pemanfaatan Media Sosial Masyarakat Sadar Wisata dalam Mempromosikan Potensi Wisata Baru dimana hasilnya menunjukan bahwa tahapan yang dilalui adalah komunikator, pesan, media dan komunikan. Di sini, media sosial memiliki manfaat untuk menyebarluaskan informasi daerah wisata, informasi perjalanan, dan menarik perhatian pengguna karena adanya fitur-fitur yang dimiliki media sosial tersebut (Nurjanah, 2018).

Berbeda dengan penelitian sebelumnya, penelitian ini fokus kepada program Cyber Public Relations PT. Kereta Api Indonesia yang merupakan perusahaan BUMN pada media sosial Instagram dalam meningkatkan layanan dan informasi publik.

\section{KERANGKA TEORI}

Public Relations. Dalam suatu organisasi diperlukan suatu wadah yang khusus untuk menangani masalah yang berkaitan dengan komunikasi baik untuk publik internal maupun eksternal. Wadah tersebut adalah public relations yang bertujuan untuk menegakan dan mengembangkan suatu citra yang menguntungkan bagi organisasi atau instansi, terhadap sasaran publik internal dan eksternal.

Public Relations adalah seni dan ilmu berbagi hasil diskusi, melindungi dan menjaga berita dan informasi yang relevan tumbuh melekat pada citra, dalam kesadaran membangun reputasi. Maka dari itu Public Relations masa kini lebih mementingkan adanya komunikasi dua arah. Berbeda dengan Public Relations di masa lampau yang berkomunikasi satu arah, saat ini seorang Public Relations juga membuka diri untuk menerima masukan dan saran, berdiskusi untuk mencapai pemahaman yang optimal terhadap suatu permasalahan.

Menurut (Cutlip, 2013) kegiatan Public Relations dapat berjalan dengan baik dan mencapai tujuannya, maka diperlukan suatu metode tahapan atau langkah proses Public Relations yang menjadi dasar, adalah:

\section{Mendefinisikan Masalah (fact finding)}

Pada tahapan ini, merupakan kegiatan pendapatan data dan fakta. Dalam tahap penelitian bias bersifat "opinion research" ialah penelitian terhadap pendapatan khalayak mengenai suatu hal atau suatu masalah. Setelah itu baru dilakukan pengevaluasi fakta-fakta dan informasi yang masuk untuk menentukan keputusan berikutnya.

\section{Perencanaan (planning)}

Dari tahap penelitian meningkatkan ke tahap perencanaan. Dalam tahap ini melakukan penyusunan daftar masalah. Dengan adanya daftar tersebut akan dapat dilakukan pemikiran dengan cepat untukmengatasinya dan sekaligus 
menentukan orang-orangnya yang akan dapat menggarap pelaksanaannya nanti. Sebuah perencanaan adalah campuran dari kebijaksanaan dan tata cara. Kebijakan dari pimpinan menjadi pedoman bagi pemikiran dan tindakan para petuigas dan tata cara meliputi pemilihan tindakan akan dijalankan kelak dalam tahap pelaksanaan.

\section{Aksi dan Komunikasi (action and communication)}

Mengambil tindakan dan berkomunikasi. Langkah yang ketiga adalah mengimplementasikan program aksi dan komunikasi yang di desain untuk mencapai tujuan spesifik untuk masing-masing public dalam rangka mencapai tujuan program.

\section{Evaluasi (evaluation)}

Langkah terakhir dalam proses ini adalah melakukan penilaian atas persiapan, implementasi, dan hasil dari program.

Public Relations dikatakan mempunyai fungsi apabila dapat menunjukan suatu kegiatan yang jelas dan berbeda dari kegiatan lainnya didalam suatu perusahaan. Fungsi Public Relations, menurut (Effendy, 2009) yaitu sebagai berikut:

1. Menunjang kegiatan manajemen dalam mencapai tujuan organisasi/perusahaan.

2. Membina hubungan harmonis antara organisasi dan publik eksternal maupun internal.

3. Menciptakan komunikasi dua arah timbal balik dengan menyebarkan informasi dari organisasi atau perusahaan kepada publik dan menyalurkan opini publik kepada organisasi atau perusahaan.

Public Relations sebagai salah satu bentuk komunikasi yang digunakan untuk penyampaian dan penyebaran informasi demi menjaga hubungan positif tidak terlepas dari media yang digunakan guna mendukung keefektifan kegiatan tersebut. Menurut (Iriantara, 2009) macam-macam media yang digunakan adalah:

1. Media cetak adalah suatu media yang penyajian pesanya tercetak, misalnya, jurnal, majalah, surat kabar (koran).

2. Media elektronik, media elektronik seperti audio (radio) dan audio visual (televisi).

a. Radio: Media komunikasi radio atau yang biasa disebut media audio merupakan media utama informasi, hiburan dan pendidikan masa yang sangat populer. Selama 60 tahun lebih radio menduduki peran utama sebagai media komunikasi

b. Televisi: Televisi merupakan suatu media komunikasi yang sering disebut audio visual, maksudnya suatu alat yang bisa memberikan informasi melalui gambar dan suara.

c. Special event, yaitu suatu kegiatan atau media pertemuan langsung (face to face), misal: presentasi, diskusi panel, seminar, pameran. dll.

d. Media luar ruang. Media luar ruang adalah suatu media komunikasi yang di sajikan di tempat umum sengaja dengan ukuran yang lebih besar misalnya sepanduk, papan reklame, benner, poster dll. 
Berdasarkan penjelasan di atas, macam-macam media Public Relations merupakan media yang bisa digunakan sebagai alat untuk penyampaian dan penyebaran informasi kepada khalayak umum. sehingga jika media yang hanya bisa digunakan untuk penyampaian dan penyebaran informasi secara pribadi, maka media tersebut tidak bisa dikatakan media Public Relations.

Cyber PR. Perkembangan Public Relations (PR) baik di Amerika Serikat ilmu atau profesi tidak bisa terlepas dari perkembangan teknologi komunikasi. Pengaruh teknologi komunikasi terhadap PR dapat dibentuk sebagai alat / media atau bentuk baru dari kegiatan PR, yang memunculkan istilah Cyber PR, PR Net dan aktivitas bentuk nama PR lain atau bidang studi di Cyber World (Soemirat \& Ardianto, 2010)

Internet adalah jaringan longgar dari ribuan jaringan komputer yang menjangkau jutaan orang di seluruh dunia. Misi awalnya adalah untuk menyediakan sarana bagi para peneliti untuk mengakses data dari komputer, namun sekarang internet telah berkembang menjadi sebuah kontes komunikasi yang sangat cepat dan efektif, sehingga telah berkembang jauh dari misi pertama.

Hingga kini PR menggunakan internet sebagai sarana untuk berkomunikasi, dan banyak komunikasi dilakukan dengan menggunakan internet lebih efisien dalam waktu dan jarak tempuh. Banyak ahli menyebutkan bahwa penggunaan internet terutama pada saat krisis komunikasi, mengidentifikasi masalah, manajemen dan komunikasi interaktif. Tujuan lainnya adalah untuk memproduksi (buletin publikasi periodik), pengiriman pesan elektronik kepada kelompok sasaran dan aplikasi internet dan web 1-1 dalam kegiatan pemasaran dan komunikasi. Sebagian besar kegiatan Public Relations di internet masih terbatas pada penggunaan media dalam satu arah, dar atas ke bawah untuk informasi penegakan masih menggunakan rumus komunikasi massa tradisional. Ditambah lagi banyak perusahaan yang belum diadopsi sebagai media PR atau perusahaan.

Saat ini banyak praktisi PR, berbicara atas nama perusahaan telah mempertimbangkan penggunaan internet sebagai salah satu strategi komunikasi PR. mereka tidak punya pilihan lain dan membuat internet menjadi bagian dari budaya perusahaan. Melalui internet itu juga setiap individu bisa menjadi publisher, atau kampanye konsumen untuk mempengaruhi perilaku konsumen, khusus dalam bidang membuka perspektif baru. Teknologi telah mengubah pola komunikasi PR sebelumnya yang masih seperti komunikasi konvensional dari atas ke bawah, bawah ke atas, horizontal, atau pola komunikasi massa. Semua itu mereka meninggalkan pola lebih aktual setelah lahirnya internet. Adapun tugas atau fokus utama E-PR (Onggo, 2009) antara lain:

1. Memaksimalkan media onlineuntuk menggunakan penyampaian pesan secara elektronik kepada publik atau organisasi media lokal, nasional, regional dan internasional. Dalam hal ini juga termasuk penyampaian datadata penunjang di media sosial.

2. Membuat produk atau bisnis perusahaan terpublikasi, sehingga seorang E-PR dituntut untuk kreatif dan cakap dalam mengolah data menjadi informasi yang di input ke dalam website. Karena sudah terpublikasi di dunia maya, EPR memiliki tanggung jawab untuk mengoperasikan peran media sosial perusahaan semaksimal mungkin. Semua itu agar para pengunjung tertarik saat mengaksesnya. 


\section{METODE PENELITIAN}

Penelitian ini menggunakan paradigma postpositivistik. Peneliti beranggapan bahwa paradigma ini adalah yang paling tepat digunakan karena penelitian ini mencoba menganalisis realita sosial yang ada dan menggambarkan serta mendeskripsikan bagaimana suatu komunikasi dapat terjalin dengan baik dalam sebuah organisasi. Metode penelitian yang digunakan adalah deskriptif analisis dengan pendekatan kualitatif. Dalam metode penelitian deskriptif analisis, peneliti mencoba untuk menggambarkan suatu fenomena lalu melakukan analisis dan menyajikan data secara sistematik sehingga mudah dipahami (Moleong, 2007). Fenomena atau kondisi yang akan digambarkan pada penelitian ini adalah Program Cyber Public Relations PT. Kereta Api Indonesia pada Media Sosial Instagram @keretaapikita dalam Meningkatkan Layanan dan Informasi Publik.

Subjek dari penelitian ini terdiri dari: 1) Head Manager Web Corporate, BUMN Portal and Social Media PT. Kereta Api Indonesia (Persero); 2) Humas dan Assistant Manager Web Corporate, BUMN Portal dan Social Media PT. Kereta Api Indonesia (Persero); 3) admin media sosial Instagram PT. Kereta Api Indonesia @keretaapikita.

Teknik pengumpulan data adalah metode yang akan digunakan untuk mengumpulkan dan menganalisis data. Teknik pengumpulan data tergantung pada data yang ingin dikumpulkan. Dalam penelitian ini ada dua, yaitu data primer yang dikumpulkan dengan menggunakan teknik wawancara mendalam (in-depth interview), dan data sekunder didapatkan dengan cara observasi dan pencarian data atau berbagai macam tulisan yang dapat dikaitkan dengan penelitian dan permasalahan yang bersumber dari surat kabar, majalah, jurnal, internet, buku-buku yang dapat menunjang data penelitian ini dan untuk menganalisa penelitian ini.

Data dan informasi yang diperoleh dari hasil wawancara akan dikumpulkan dan dianalisis berdasarkan metode tertentu. Pada mulanya peneliti akan menggunakan metode reduksi yang secara garis besar akan mereduksi seluruh pernyataan hasil wawancara dan dirumuskan menjadi esensi pengalaman. Setelah proses reduksi, penelitian akan menyajikan data dengan langkah- langkah atau tahapan mengorganisasikan data yaitu menjalin data yang satu dengan kelompok data yang lain sehingga seluruh data yang dianalisis benar- benar dilibatkan dalam satu kesatuan karena dalam penelitian kualitatif data sangat mungkin bertumpuk. Data kemudian tersaji berupa kelompok-kelompok atau gugusan gugusan yang kemudian saling dikait-kaitkan sesuai dengan kerangka teori yang digunakan. Setelah itu dilakukan penarikan serta pengujian kesimpulan (Sugiyono, 2015).

\section{PEMBAHASAN}

Setelah melakukan pengumpulan data melalui wawancara, peneliti mendapatkan informasi terkait implementasi program Cyber Public Relations yang dilakukan oleh PT. Kereta Api Indonesia dalam mengelola informasi publik di media sosial Instagram. Media sosial Instagram PT. Kereta Api Indonesia (Persero) telah digunakan sejak tahun 2012, dan sampai saat ini peminatnya semakin tinggi karena internet semakin dekat dengan masyarakat. Tujuan penggunaan Instagram utamanya adalah untuk menerima dan memberikan informasi dari dan untuk masyarakat, maupun menyampaikan pendapat atau keluhan kepada PT. Kereta Api Indonesia (Persero). Divisi Humas PT. Kereta Api Indonesia (Persero) sengaja membuat 
Instagram @keretaapikita untuk memudahkan masyarakat dalam melihat informasi yang diberikan PT. Kereta Api Indonesia (Persero) secara online dan bisa diakses dimana pun dan kapanpun.

Pada tanggal 10 April 2012, di tiga tahun pertama, akun Instagram PT. Kereta Api Indonesia (Persero) belum begitu banyak pengikutnya, yaitu hanya sekitar 2.636 orang dan 550 post. Namun seiring dengan makin majunya teknologi, khususnya media sosial berdampak positif bagi PT. Kereta Api Indonesia (Persero) di mana akun Instagramnya mengalami kenaikan yang cukup drastis yaitu 513.000 orang, dengan jumlah post sebanyak 2.167 .

Melalui Instagram, PT. Kereta Api Indonesia (Persero) dapat menyebarkan informasi secara luas, sehingga dapat diterima dengan cepat oleh para khalayak atau publik. Hal ini dipertegas oleh Bapak Hendreas Andri Pratama selaku Humas dan Assistant Manager Web Corporate dimana beliau mengatakan bahwa media sosial Instagram @keretaapikita merupakan salah satu terobosan teknologi yang dapat memberikan kemudahan serta kenyamanan dalam penyampaian informasi ke masyarakat. Selain itu, akun @keretaapikita bukan hanya memberikan informasi dari PT. Kereta Api Indonesia (Persero) ke masyarakat tetapi juga memberikan wadah untuk masyarakat memberikan masukan untuk PT. Kereta Api Indonesia (Persero) untuk lebih maju lagi. Dan di media sosial Instagram @keretaapikita juga masyarakat bisa menuangkan ekpresinya dengan cara memposting foto mereka saat melakukan perjalanan menggunakan kereta api dan nantinya admin dapat memposting ulang dan memberikan "like" kepada mereka.

Berdasarkan hasil dari wawancara, dapat dilihat bahwa yang menjadi dasar dari implementasi digital Public Relations di PT. Kereta Api Indonesia (Persero) adalah empat hal di bawah ini:

1. Menunjang kegiatan manajemen dalam mencapai tujuan organisasi;

2. Membina hubungan harmonis antara organisasi dengan publik eksternal maupun internal;

3. Menciptakan komunikasi dua arah secara timbal balik dengan menyebarluaskan informasi dari perusahaan atau organisasi kepada public dan menyalurkan opini publik kepada organisasi; dan

4. Melayani publik dan menasehati pimpinan organisasi kepentingan umum.

Untuk mencapai target atau tujuan yang diinginkan oleh perusahaan, semua bentuk informasi yang ada di akun Instagram @keretaapikita melalui proses manajemen Public Relations yang terdiri dari: riset, perencanaan, pelaksanaan dan evaluasi. Penelitian ini fokus pada tahapan implementasi atau disebut juga tahap pelaksanaan yang dilakukan setelah melakukan perencanaan. Tahap pelaksanaan tidak terlepas dari perencanaan yang baik tentang bagaimana mengkomunikasikan dan apa yang dikomunikasikan sehingga menimbulkan kesan-kesan yang secara positif mempengaruhi pihak-pihak yang dianggap penting dan berpotensi dalam upaya memberikan dukungan sepenuhnya. Bagaimana humas mengkomunikasikan sebuah informasi, tidak terlepas dari tujuan yang hendak dicapai melalui kegiatan kehumasan yang akan dilakukan oleh PT. Kereta Api Indonesia (Persero).

Implementasi program kehumasan dilakukan tidak hanya untuk mengkomunikasikan pesan terhadap publik tetapi juga untuk menyelesaikan masalah yang dihadapi perusahaan atau organisasi. Humas PT. Kereta Api Indon esia 
(Persero) yang mengelola aktivitas di akun Instagram @keretaapikita menyatatakan bahwa dalam menjalankan rencana dan programnya di akun @keretaapikita menyasar kepada seluruh masyarakat pengguna kereta api dan followers @keretaapikita. PT. Kereta Api Indonesia (Persero) sengaja membuat berbagai program, mulai dari pemberian informasi, mengadakan event, dan memberikan giveaway agar masyarakat merasa dekat dengan perusahaan. Dengan begitu masyarakat akan merasa dihargai. Masyarakat juga boleh menyampaikan keluhan pada pihak perusahaan melalui Humas lewat media sosial Instagram tersebut.

Dalam menjalankan aktivitas Cyber PR, PT. Kereta Api Indonesia (Persero) telah melakukan terobosan dalam menjangkau khalayaknya, sehingga dapat menyajikan manfaat yang memang dibutuhkan oleh konsumen tersebut. Diantaranya adalah menyajikan informasi seputar layanan, informasi mengenai tiket dan informasi mengenai perjalanan kereta api secara online yang bisa diakses dengan menggunakan smartphone. Dengan adanya akun instagram @keretaapikita ini masyarakat tidak perlu antre atau jauh-jauh datang ke stasiun hanya untuk mencari informasi yang dibutuhkan.

Implementasi aktivitas Cyber PR PT. Kereta Api Indonesia (Persero) dijalankan oleh divisi Humas dimana Assistant Manager Web Corporate, BUMN Portal and Social Media ditunjuk sebagai pelaksana tugas. Pemilihan aktivitas komunikasi digital ini dilakukan guna menginformasikan, membujuk, serta mengingatkan konsumen baik secara langsung maupun tidak langsung di akun instagram PT. Kereta Api Indonesia (Persero).

Humas PT. Kereta Api Indonesia (Persero) berperan sebagai agen publisitas guna mempublikasikan informasi maupun berita seputar perusahaan. Menurut Bapak Ahmad selaku Head Manager Web Corporate, BUMN Portal and Social Media PT. Kereta Api Indonesia (Persero), humas berperan sebagai agen publisitas jadi tugasnya adalah mempublikasikan kegiatan atau informasi tentang PT. Kereta Api Indonesia (Persero) kepada masyarakat melalui media sosial atau media massa. Humas juga berperan dalam menjaga nama baik PT. Kereta Api Indonesia (Persero). Terkadang pihak pengelola media sosial juga menghapus komentar yang ingin menjatuhkan PT. Kereta Api Indonesia (Persero) agar tidak terprovokasi.

Cyber Public Relations pada dasarnya merupakan aktivitas kehumasan yang menggunakan media internet, salah satunya adalah melalui media sosial. Implementasi Cyber Public Relations yang dilakukan oleh PT. Kereta Api Indonesia (Persero) dilakukan oleh tim Humas serta melewati tahapan manajemen Public Relations yang meliputi: Fact Finding, Perencanaan, Aksi dan Komunikasi, serta Evaluasi.

Implementasi Cyber Public Relations PT. Kereta Api Indonesia tidak lepas dari tujuan utamanya, yang diantaranya adalah menunjang kegiatan manajemen dalam mencapai tujuan organisasi, membina hubungan harmonis antara organisasi dengan publik eksternal maupun internal, menciptakan komunikasi dua arah secara timbal balik dengan menyebarluaskan informasi dari perusahaan atau organisasi kepada publik dan menyalurkan opini publik kepada organisasi, dan melayani publik dan menasehati pimpinan organisasi kepentingan umum.

Jika dikaitkan dengan tugas atau fokus utama E-PR (Onggo, 2009) yang terdiri dari: 
1. Memaksimalkan media online untuk menggunakan penyampaian pesan secara elektronik kepada publik atau organisasi media lokal, nasional, regional dan internasional, termasuk penyampaian data-data penunjang di media sosial.

Dalam hal ini, PT. Kereta Api Indonesia (Persero) menggunakan media sosial Instagram untuk menyampaikan pesan kepada publik. Misalnya saja, untuk pengembalian tiket kereta api mudik 2020 yang ternyata harus dibatalkan karena pandemi virus corona, mereka secara informatif menyampaikan cara untuk memproses pengembalian dana tersebut. Selain itu, secara interaktif juga mereka membalas komentar yang ditulis serta pertanyaan yang terkait dengan hal tersebut. Jadi, komunikasi dua arah (two-way communication) juga dapat tercipta di media sosial.

2. Membuat produk atau bisnis perusahaan terpublikasi, sehingga PR dituntut untuk kreatif dan cakap dalam mengolah data menjadi informasi yang diinput ke dalam website/ media sosial. Pada poin ini, publikasi yang dilakukan oleh Humas PT. Kereta Api Indonesia (Persero) di akun Instagram @keretaapikita antara lain adalah event yang dilakukan di dalam kereta, seperti fashion show, pertunjukan barongsai dalam rangka merayakan Imlek, dan hal lainnya. Tak jarang juga mereka mempublikasi produk-produk baru seperti gerbong kereta luxury, pembukaan stasiun baru, pembukaan rute kereta api baru, dll.

Bentuk aktivitas Cyber Public Relations yang telah dilakukan di akun @keretaapikita antara lain: memberikan informasi tentang PT. Kereta Api Indonesia (Persero), layanan kereta api, layanan stasiun sampai event dan inovasi yang telah dilakukan. Bahkan beberapa kali dilakukan kegiatan giveaway agar menarik perhatian masyarakat untuk memfollow akun tersebut. Dalam hal ini berbagai cara dan teknik digunakan diantaranya yaitu pendekatan terhadap masyarakat. Dalam melakukan proses komunikasi digital di media sosial Instagram @keretaapikita, PT. Kereta Api Indonesia (Persero) menggunakan komunikasi yang konstan, respon yang cepat, interaktif dan dua arah (two-way) yang sesuai dengan apa yang dikemukakan oleh (Onggo, 2009).

\section{KESIMPULAN}

Berdasarkan hasil penelitian di atas, dapat ditarik kesimpulan bahwa implementasi program Cyber Public Relations PT. Kereta Api Indonesia dalam mengelola informasi publik di media sosial Instagram meliputi memberikan informasi tentang PT. Kereta Api Indonesia (Persero), layanan kereta api, layanan stasiun sampai event dan inovasi yang telah dilakukan, bahkan beberapa kali dilakukan kegiatan giveaway agar menarik perhatian masyarakat untuk memfollow akun tersebut.

Implementasi Cyber Public Relations PT. Kereta Api Indonesia tidak lepas dari tujuan utamanya, yang diantaranya adalah menunjang kegiatan manajemen dalam mencapai tujuan organisasi, membina hubungan harmonis antara organisasi dengan publik eksternal maupun internal, menciptakan komunikasi dua arah secara timbal balik dengan menyebarluaskan informasi dari perusahaan atau organisasi kepada 
publik dan menyalurkan opini publik kepada organisasi, dan melayani publik dan menasehati pimpinan organisasi kepentingan umum.

Berdasarkan kesimpulan, maka saran yang dapat diberikan oleh peneliti untuk perusahaan adalah menambahkan admin untuk mengelola media sosial agar tidak hanya aktif di Instagram saja tetapi juga di media sosial lain. Selain itu, dengan penambahan admin diharapkan respon yang diberikan kepada masyarakat lebih cepat sehingga pelayanan menjadi lebih baik.

\section{DAFTAR PUSTAKA}

Cutlip, S. M. (2013). Effective Public Relations Edisi ke-11. Jakarta: Kencana Media Group.

Djuraid, H. M. (2013). Jonan dan Evolusi Kereta Api Indonesia. Jakarta: BUMN Track.

E.B, G. A. (2014). Strategi Cyber Public Relations dalam Pembentukan Citra Institusi Pendidikan Tinggi Swasta. THE MESSENGER, Volume VI, Nomor 1, 1-7.

Effendy, O. U. (2009). Ilmu Komunikasi Teori dan Praktek. Bandung: PT Remaja Rosdakarya.

Gabrina, I. d. (2013). Analisis Strategi Cyber PR PT. Pertamina (Persero) untuk Sosialisasi Penyesuaian Harga LPG 12 kg (Studi Kasus pada Kompetisi Blog Kompasiana oleh Pertamina). Journal Communication Spectrum Vol. 3, No. 2.

Iriantara, Y. (2009). Media Relations: Konsep, Pendekatan dan Praktik. Bandung: Simbiosa Rekatama Media.

Januarti, D. T. (2014). Kecenderungan Isi Pemberitaan Layanan PT. Kereta Api Indonesia di Harian KOMPAS Periode Januari - Mei 2011. Jakarta: Universitas Mercu Buana.

Kemp, S. (2020, February 18). Digital 2020: Indonesia. Retrieved March 20, 2020, from datareportal.com: https://datareportal.com/reports/digital-2020-indonesia

Kusuma, K. (2018). Activities of Cyber PR of O Channel TV in Promoting their Company on Instagram. American Journal of Humanities and Social Sciences Research, 50-56.

Moleong, L. J. (2007). Metodologi Penelitian Kualitati. Bandung: PT Remaja Rosdakarya.

Nurjanah. (2018). Pemanfaatan Media Sosial Masyarakat Sadar Wisata Dalam Mempromosikan Potensi Wisata Baru. Medium Jurnal Ilmiah Fakultas Ilmu Komunikasi Universitas Islam Riau, Vol. 6 No. 2, 39-50.

Onggo, B. J. (2009). Cyber Public Relations. Jakarta: PT. Media Elex Komputindo (Gramedia Group). 
Volume 8 Nomor 1

ISSN: 2303-0194

Soemirat, S., \& Ardianto, E. (2010). Dasar-Dasar Public Relations. Bandung: Remaja Rosdakarya.

Sugiyono. (2015). Metode Penelitian Kuantitatif, Kualitatif, dan R \& D. Bandung: Alfabeta.

Susilo, A., \& Putra, R. K. (Juli 2019). Membangun Brand Awareness Menggunakan Strategi Cyber PR. Communicology Vol. 7 No. 1, 32-46. 